\title{
Long-Term Impact of Wastewater Irrigation on Soil Pollution and Degradation: A Case Study from Egypt
}

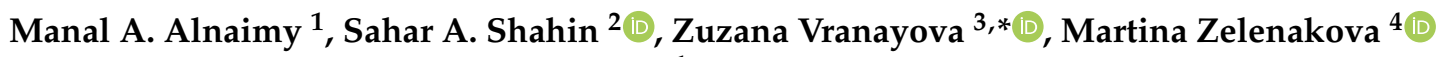 \\ and Enas Mohamed Wagdi Abdel-Hamed ${ }^{1}$ \\ 1 Soil Science Department, Faculty of Agriculture, Zagazig University, Zagazig 44511, Egypt; \\ dr_manalalnaimy@yahoo.com (M.A.A.); enaswagdi@yahoo.com (E.M.W.A.-H.) \\ 2 Soils and Water Use Department, Agriculture and Biological Division, National Research Centre, \\ Giza 12622, Egypt; saharselim98@yahoo.com \\ 3 Department of Building Facilities, Faculty of Civil Engineering, Technical University of Kosice, \\ 04200 Kosice, Slovakia \\ 4 Department of Environmental Engineering, Faculty of Civil Engineering, Technical University of Kosice, \\ 04200 Kosice, Slovakia; martina.zelenakova@tuke.sk \\ * Correspondence: zuzana.vranayova@tuke.sk; Tel.: +421-907178151
}

check for

updates

Citation: Alnaimy, M.A.; Shahin, S.A.; Vranayova, Z.; Zelenakova, M.; Abdel-Hamed, E.M.W. Long-Term Impact of Wastewater Irrigation on Soil Pollution and Degradation: A Case Study from Egypt. Water 2021, 13, 2245. https://doi.org/10.3390/ w13162245

Academic Editor: Alicia Ronda Gálvez

Received: 13 July 2021

Accepted: 10 August 2021

Published: 17 August 2021

Publisher's Note: MDPI stays neutral with regard to jurisdictional claims in published maps and institutional affiliations.

Copyright: (c) 2021 by the authors. Licensee MDPI, Basel, Switzerland. This article is an open access article distributed under the terms and conditions of the Creative Commons Attribution (CC BY) license (https:// creativecommons.org/licenses/by/ $4.0 /)$.

\begin{abstract}
There is consensus on the impact of wastewater irrigation on soil properties and heavy metal accumulation. The studies that show the impact of temporal changes as a result of different longterm additions of wastewater on the heavy metal accumulation and degradation of soil are extremely limited. This study was carried out to assess heavy metal contamination in soils irrigated with wastewater for more than 30 years in Egypt. A total number of 12 irrigation water samples and 12 soil profiles were collected during 2020 and were chemically characterized. The results showed that soils irrigated with wastewater over the long term contained significantly higher concentrations of heavy metals compared to fields irrigated with fresh water. Heavy metal levels in water and soil samples were within the permissible limits, with the exception of $\mathrm{Cd}$ concentration in water $\left(0.03 \mathrm{mg} \mathrm{L}^{-1}\right)$. Continuous cultivation for a long period of time (30 years) using raw urban wastewater application has led to the adverse effect of increasingly available $\mathrm{Pb}$ concentration $\left(5.44 \mathrm{mg} \mathrm{kg}^{-1}\right)$. Similar temporal behavior was seen for $\mathrm{Cd}$ and $\mathrm{Fe}$, which increased by 0.98 and $11.2 \mathrm{mg} \mathrm{kg}^{-1}$, respectively, after 30 years. The heavy metals in wastewater-irrigated soils significantly increased in clayey soils, as compared to sandy soils irrigated from the same source. Our findings provide important information for decision makers in Egypt and similar countries for the development of a strategy for the use of wastewater in irrigation for sustainable agricultural management.
\end{abstract}

Keywords: wastewater; heavy metals; soil pollution; soil salinization; arid and semiarid regions

\section{Introduction}

In the most arid and semiarid regions of the world, water security is considered to be one of the main problems on the path to sustainable agriculture, due to water restrictions and increased water consumption [1,2]. The use of low-quality water resources is considered as a solution for agricultural irrigation, which comprises the largest global consumption of water [3-6]. Using wastewater for irrigation without risk assessments and management can pose a great risk to the quality of water and soil, and eventually to human health [7-11]. Water pollution control and environmental protection systems are necessary to preserve living conditions for the future [12,13].

Several laboratory and field experiments on the reuse of treated wastewater for irrigation have been undertaken around the world. This research has studied the effects of reuse on soil, plants, crops, water, and public health, as well as the economic viability of this method. Ibekwe et al. [14] proposed using treated wastewater effluent for irrigation in agriculture as an alternative water source because of the increasing scarcity of fresh 
water in arid and semiarid regions of the world. However, significant barriers exist to widespread adoption due to potential contaminants that may have adverse effects on soil quality and public health. Bedbabis et al. [15] suggested the reuse of treated wastewater in agricultural applications in Tunisia as a sustainable solution to water scarcity. The authors conducted their research in an olive orchard planted on sandy soil and subjected to irrigation treatments and observed a significant decrease of $\mathrm{pH}$ and a significant increase of OM, SAR, and EC in the soil.

In general, wastewater irrigation enriches the soil with vital macro and micronutrients, including nitrogen $(\mathrm{N})$, phosphorus $(\mathrm{P})$, potassium $(\mathrm{K})$, zinc $(\mathrm{Zn})$, iron $(\mathrm{Fe})$, manganese $(\mathrm{Mn})$, and copper $(\mathrm{Cu})$, as a result of its composition [16]. Wastewater may have a high organic matter content; as a result, wastewater could be a sustainable and beneficial supply of organic matter for soils and can encourage plant development [17].

Egypt is among the ten countries that will be exposed to a water shortage problem by the year 2025: a shortage estimated to be about 13.5 billion cubic meters per year. Thus, there is a need to reuse wastewater in agriculture irrigation [18-20]. In Egypt, the water shortage in the El-Fayoum Governorate is compensated by drainage reuse, which negatively affects the soil and plants [21-23]. Its drainage system is fed by two main drains, El-Bats and El-Wadi; water from these drains is characterized by high pollution concentrations as a result of receiving large amounts of domestic, industrial and agricultural wastewater [24] The remaining drainage water flows into Quarun Lake and Rayan Channel, where any excess of drainage water beyond their capacity floods the surrounding soils $[25,26]$.

Wastewaters commonly contain high amounts of plant nutrients and thus reduce the need for costly inorganic fertilizers and enhance soil fertility and crop production [27]. The practice of wastewater reuse in agriculture is a traditional way to confront the excessive pressure on freshwater resources [28]. Regardless of the benefits, the use of wastewater may have impacts on the physical and chemical properties of soils and, eventually, on crops [29-32]. Therefore, using wastewater in agriculture can cause soil salinization-an increase of sodium ions relative to other cations-and the accumulation of heavy metals in the soil and crops, causing potential health risk in the long term. This depends largely on the source of the wastewater and treatments applied as well as the inherent soil characteristics [16,33].

In Egypt, there is consensus in the scientific literature on the impact of wastewater irrigation on the physical and chemical properties of soil as well as the accumulation of heavy metals in soil and plants [34-37]. However, there is little information on the long-term impact of different additions of wastewater, as compared to fresh water, on soil properties and heavy metal accumulations. Consequently, there is an urgent need to understand the potential environmental impacts of this practice, especially in developing countries such as Egypt. The widely applied solution to this problem is based on keeping heavy metals below the permissible limits in soil and agricultural crops. The aim of this study is to trace the effects of wastewater, which is used in irrigation for varying periods of time, on soil pollution and degradation. The outcome of this study can provide key information on heavy metals, which is useful in achieving sustainable agricultural management.

\section{Materials and Methods}

\subsection{Site Specification}

The study was conducted in the northern part of El-Fayoum Governorate, Egypt (longitudes of $30^{\circ} 32^{\prime} \mathrm{E}$ to $30^{\circ} 50^{\prime} \mathrm{E}$, and latitudes of $29^{\circ} 21^{\prime} \mathrm{N}$ to $29^{\circ} 34^{\prime} \mathrm{N}$ ), which is located in the Eocene Limestone plateau, $50 \mathrm{~m}$ below mean sea level. The climate is characterized by long, dry, hot summers and short, nearly rainless, cold winters. The soil moisture is torric, and the soil temperature regime is hyperthermic. The solum thickness of the studied soil profiles is $90 \mathrm{~cm}$, indicating that all sites have moderately deep soils. The land cover includes wheat, fruit trees (mango), clover, and cotton. The topography of the landscape is nearly level to gently sloping, with the three physiographic units of lacustrine plain, fluvio-lacustrine plain, and alluvial plain [38]. All horizons have a hue of $10 \mathrm{YR}$ 
in dry and moist conditions, ranging between light brown (10 YR 5/2) to yellow (6/3). These colors, in moist conditions, become pale brown (10 YR 4/2) and brownish yellow (10 YR 6/2). The surface horizons have a lower color value than the subsequent subsurface horizons. The soil structure varies from massive in the uppermost surface to sub-angular and blocky moving downwards. The soil consistency agrees well with textural variations, being non-sticky to moderately sticky and non-plastic to moderately plastic in the coarse and fine textured horizons, respectively. The soils of the study area can be classified into the order of Vertisols, suborder of Torrerts, and main soil group of Haplotorrerts, with the two subgroups of Sodic Haplotorrerts and Typic Haplotorrerts, according to [39]. The Nile canal through the Bahr Yussef canal, which enters Fayoum from the eastern edge at El Lahun ( $+26 \mathrm{~m}$ above sea level), is the main irrigation water source. It carries Nile water as well as agricultural effluents from the two main drains of El-Wadi and El-Bats [40,41].

\subsection{Water Sampling}

Twelve water samples were taken in 2020 from different irrigation sources in the study area. Source 1 (S1) represented fresh water (sample Nos. 1, 2, 3, and 4), source 2 (S2) represented agricultural wastewater (sample Nos. 5, 6, 7, and 8), and source 3 (S3) represented raw urban wastewater (sample Nos. 9, 10, 11, and 12). The water samples were collected in $1.5 \mathrm{~L}$ polyethylene bottles at three different agricultural sites, kept cool by preserving in ice, and transferred to the laboratory. Four water samples were collected at each site on the same date. $\mathrm{pH}$ and electric conductivity (EC) were measured in situ. Heavy metals $(\mathrm{Pb}, \mathrm{Cd}, \mathrm{Cu}, \mathrm{Ni}, \mathrm{Fe}, \mathrm{Mn}$, and $\mathrm{Zn})$ in irrigation water samples were directly determined after filtration according to [42]. Chlorides $\left(\mathrm{Cl}^{-}\right.$; Mohr method), calcium $\left(\mathrm{Ca}^{2+}\right)$, and magnesium $\left(\mathrm{Mg}^{2+}\right)$ (by complexometry, with a solution of EDTA, and as a colored indicator: murixide), sodium $\left(\mathrm{Na}^{+}\right)$and potassium $\left(\mathrm{K}^{+}\right)$(by a flame photometer), carbonates $\left(\mathrm{CO}_{3}{ }^{2-}\right)$ and bicarbonates $\left(\mathrm{HCO}_{3}{ }^{-}\right)$(by titration method using phenolphthalein as an indicator for the former and methyl orange as an indicator for the latter) were analyzed according to [43]. Sulphate $\left(\mathrm{SO}_{4}{ }^{2-}\right)$ was calculated by subtracting the total soluble anions from the total soluble cations. The $\mathrm{Na}, \mathrm{Ca}$, and $\mathrm{Mg}\left(\mathrm{mmol} \mathrm{L}^{-1}\right)$ solution content was used to calculate the sodium adsorption ratio (SAR) (Equation (1)):

$$
\mathrm{SAR}=\frac{\mathrm{Na}^{+}}{\sqrt{\left(\mathrm{Ca}^{2+}+\mathrm{Mg}^{2+}\right) / 2}}
$$

\subsection{Soil Sampling}

Twelve soil profiles were carried out in 2020 from three different types fed by different irrigation sources (four agricultural fields for each source). Profile Nos. 1, 2, 3, and 4 represented the soils irrigated with Nile water (control); profile Nos. 5, 6, 7, and 8 represented the soils irrigated with agricultural wastewater; profile Nos. 9, 10, 11, and 12 represented the soils irrigated with raw urban wastewater. All the studied soils had an agricultural age of more than 30 years, but the profiles irrigated with agricultural wastewater or raw urban wastewater had different time periods of wastewater use (10,15,20, and 30 years). All selected soil types were irrigated by the submersion method and carried out on horizons of $0-30,30-60$, and $60-90 \mathrm{~cm}$. The measurement of the soil's available heavy metal content of $\mathrm{Pb}, \mathrm{Cd}, \mathrm{Cu}, \mathrm{Ni}, \mathrm{Fe}, \mathrm{Mn}$, and $\mathrm{Zn}$ was performed as explained by [44] and determined using an atomic absorption spectrophotometer (Analytic Jena, AS 51S). pH (soil paste extract) was determined using a Hanna pH-meter (model PH211). Soil EC was assessed from soil paste extract using a conductivity meter. Organic matter (OM) was measured according to [45]. Cation exchange capacity (CEC) was measured according to the ammonium acetate method [46]. Available nitrogen $(\mathrm{N})$ was extracted by $\mathrm{K}_{2} \mathrm{SO}_{4}$, and determined by the steam distillation procedure using $\mathrm{MgO}$ Devarda alloy according to the Bremner and Keency method, as described by [47]. Available phosphorus (P) was extracted using $0.5 \mathrm{~N} \mathrm{NaHCO}_{3}$ at $\mathrm{pH} 8.5$ and determined using the ascorbic acid method [48]. Available potassium $(\mathrm{K})$ was extracted using $1.0 \mathrm{~N}$ ammonium acetate at $\mathrm{pH} 7.0$ and determined 
using a flame photometer [46]. Soil texture was determined using the international pipette method $[49,50]$.

\subsection{Data Analysis}

Collected data were subjected to the one-way analysis of variance (ANOVA) test, and differences between means were determined according to the Duncan significant difference test $(p<0.05)$, using SPSS software to assess the differences in soil properties between the three irrigation practices. Pearson correlation coefficient analysis was used to examine the correlation between irrigation water sources and soil pollution.

\section{Results and Discussion}

\subsection{Irrigation Water Chemical Characteristics}

The chemical properties of the irrigation water from the three sources, including the four samples for each source, as well as the safe limits specified in [51] are presented in Table 1. The average $\mathrm{pH}$ values were 7.32, 7.21, and 7.11 for S1, S2, and S3 sources, respectively. The recorded values were less than the FAO standards for irrigation water (7.60). The $\mathrm{pH}$ values obtained for S3 were slightly lower than recorded for the other sources. The EC values obtained were $0.62,1.45$, and $3.55 \mathrm{dS} \mathrm{m}^{-1}$ for S1, S2, and S3 sources, respectively. Compared to the FAO limits $\left(<3 \mathrm{dS} \mathrm{m}^{-1}\right)$, the EC values for the S2 and S3 sources recorded in the present study were higher due to agricultural water leaching and discharge effluents. The obtained values revealed strong mineralization of the water, with the EC exceeding $1 \mathrm{dS} \mathrm{m}^{-1}$ [52]. The mean concentration of cations for the three irrigation water sources (S1, S2, and S3) is as follows: the $\mathrm{Na}^{+}$concentration was 5.0, 10.0 , and $25.0 \mathrm{mmol}_{\mathrm{c}} \mathrm{L}^{-1}$, respectively; the $\mathrm{K}^{+}$concentration was $0.1,0.2$, and $0.6 \mathrm{mmol}_{\mathrm{c}}$ $\mathrm{L}^{-1}$, respectively; the $\mathrm{Ca}^{2+}$ concentration was $1.5,2.5$, and $5.0 \mathrm{mmol}_{\mathrm{c}} \mathrm{L}^{-1}$, respectively; the $\mathrm{Mg}^{2+}$ concentration was $0.5,1.5$, and $2.5 \mathrm{mmol}_{\mathrm{c}} \mathrm{L}^{-1}$, respectively. Meanwhile, the concentration of $\mathrm{Cl}^{-}, \mathrm{HCO}_{3}{ }^{-}$, and $\mathrm{SO}_{4}{ }^{2-}$ was $\left(5.0,9.0\right.$, and $\left.15.0 \mathrm{mmol}_{\mathrm{C}} \mathrm{L}^{-1}\right),(1.0,2.0$, and $\left.3.0 \mathrm{mmol}_{\mathrm{c}} \mathrm{L}^{-1}\right)$, and $\left(1.1,3.2\right.$, and $\left.15.1 \mathrm{mmol}_{\mathrm{c}} \mathrm{L}^{-1}\right)$, respectively. Furthermore, wastewater includes higher amounts of soluble salts than fresh water, which may cause soil salinization or an increase in $\mathrm{Na}^{+}$ions compared to other cations [16]. Sodium adsorption ratio (SAR) values were 5.0, 7.1, and 12.9 for S1, S2, and S3 sources, respectively. These values are higher than FAO safe limits (3.0), owing the wastewater quality generated by agricultural effluents and raw urban sources. Irrigation water containing this range of SAR can adversely affect soil structure, additionally reducing the permeability of irrigated soils [53]. The values for $\mathrm{Pb}, \mathrm{Cu}, \mathrm{Ni}, \mathrm{Fe}, \mathrm{Mn}$, and $\mathrm{Zn}$ were low compared to FAO safe limits for all sources, except for $\mathrm{Cd}$, which exceeded the FAO limit $\left(0.01 \mathrm{mg} \mathrm{L}^{-1}\right)$ in the $\mathrm{S} 3$ source $\left(0.03 \mathrm{mg} \mathrm{L}^{-1}\right)$.

\subsection{Temporal Changes in Soil Heavy Metal Content Due to Wastewater Addition}

The temporal changes as a result of using different irrigation water sources on available heavy metal concentration in soils are shown in Figure 1. Our findings show that the sites with soils irrigated by Nile water show a trend in the values of pb, $\mathrm{Cd}, \mathrm{Cu}, \mathrm{Ni}, \mathrm{Fe}, \mathrm{Mn}$, and Zn over different time (10-15-20-30 years). Additionally, there is no obvious increase in their concentration from 10 to 30 years, indicating low contamination levels in Nile water. The soils irrigated with agricultural effluents showed high values of available heavy metals $(\mathrm{Pb}, \mathrm{Cd}, \mathrm{Cu}$, and $\mathrm{Zn})$, which reflect a high degree of pollution in comparison to the values for the control locations (Nile water). The highest mean values of available $\mathrm{Pb}, \mathrm{Cd}, \mathrm{Cu}$, and $\mathrm{Zn}$ were $2.53,0.31,1.61$, and $0.92 \mathrm{mg} \mathrm{kg}^{-1}$, respectively, from soil that had been irrigated for 30 years using agricultural wastewater. However, the available $\mathrm{Ni}, \mathrm{Fe}$, and $\mathrm{Mn}$ have an irregular trend over different time periods (10-15-20-30 years). In contrast, continuous cultivation using raw urban wastewater has resulted in increasing available heavy metal concentrations over different time, with the concentration increasing from 3.32 to 5.44 , 0.59 to $0.98,9.11$ to 11.19 , and 0.44 to $1.6 \mathrm{mg} \mathrm{kg}^{-1}$ for $\mathrm{Pb}, \mathrm{Cd}, \mathrm{Fe}$, and $\mathrm{Zn}$, respectively, over 30 years; while there was no clear difference between the values of available $\mathrm{Cu}, \mathrm{Ni}$, and Mn over the different time periods. 
Table 1. Average values of physico-chemical parameters and concentration of heavy metals in irrigation water sources.

\begin{tabular}{ccccc}
\hline Parameter & S1 & S2 & S3 & Safe Limit [51] \\
\hline $\mathrm{pH}$ & 7.32 & 7.21 & 7.11 & 7.60 \\
$\mathrm{EC}_{\mathrm{w}}, \mathrm{dS} \mathrm{m} \mathrm{m}^{-1}$ & 0.62 & 1.45 & 3.55 & $<3$ \\
& Cations, $\mathrm{mmol}_{\mathrm{C}} \mathrm{L}^{-1}$ & & \\
Sodium $\left(\mathrm{Na}^{+}\right)$ & 5.0 & 10.0 & 25.0 & $0-40$ \\
Potassium $\left(\mathrm{K}^{+}\right)$ & 0.1 & 0.2 & 0.6 & $0-2$ \\
Calcium $\left(\mathrm{Ca}^{2+}\right)$ & 1.5 & 2.5 & 5.0 & $0-20$ \\
Magnesium $\left(\mathrm{Mg}^{2+}\right)$ & 0.5 & 1.5 & 2.5 & $0-5$ \\
& Anions, mmol $_{\mathrm{c}} \mathrm{L}^{-1}$ & & \\
Chloride $\left(\mathrm{Cl}^{-}\right)$ & 5.0 & 9.0 & 15.0 & $0-30$ \\
Bicarbonate $\left(\mathrm{HCO}_{3}{ }^{-}\right)$ & 1.0 & 2.0 & 3.0 & $0-10$ \\
Sulphate $\left(\mathrm{SO} 4^{2-}\right)$ & 1.10 & 3.20 & 15.10 & $0-20$ \\
SAR & 5.00 & 7.07 & 12.91 & 3.00 \\
Lead $(\mathrm{Pb})$ & Heavy metals, $\mathrm{mg} \mathrm{L}^{-1}$ & & \\
Cadmium $(\mathrm{Cd})$ & 0.002 & 0.004 & 0.006 & 5.00 \\
Copper $(\mathrm{Cu})$ & 0.003 & 0.010 & 0.030 & 0.01 \\
Nickel $(\mathrm{Ni})$ & 0.02 & 0.03 & 0.03 & 0.20 \\
Iron $(\mathrm{Fe})$ & 0.03 & 0.10 & 0.10 & 0.20 \\
Manganese $(\mathrm{Mn})$ & 0.10 & 0.30 & 0.40 & 5.00 \\
Zinc $(\mathrm{Zn})$ & 0.002 & 0.010 & 0.010 & 0.20 \\
\hline
\end{tabular}

S1, S2, and S3 refer to Nile water, agricultural wastewater, and raw urban wastewater, respectively; $\mathrm{dSm}^{-1}$ $=$ deciSiemen metre ${ }^{-1}$ in S.I. units (equivalent to $1{\mathrm{mmho} \mathrm{cm}^{-1}=1 \text { millimmho centimeter }}^{-1}$ ).

High concentrations of heavy metals in sediments may result in the transportation of these metals in suspended solids in the drain bed and sides [54]. Using wastewater in irrigation could enrich soils with heavy metals to levels that may pose a potential risk to the environment, soil quality, and human health [55]. Heavy metal elements are concentrated in the soil mostly in the surface layer, within $50 \mathrm{~cm}$ from the soil surface; their vertical distribution varies with soil texture [56]. Recently, Dotaniya et al. [57] and Ahmad et al. [58] reported that sewage water may contain low concentrations of heavy metals; however, the long-term use of this water could result in the accumulation of significant amounts of heavy metals in soil. They added that long-term irrigation of clay soil with sewage wastewater increases its available $\mathrm{Cu}, \mathrm{Cd}, \mathrm{Pb}, \mathrm{Cr}, \mathrm{Ni}$, and $\mathrm{Zn}$. Similar results have noted increases in available $\mathrm{Pb}, \mathrm{Cu}, \mathrm{Cd}$, and $\mathrm{Ni}$ following wastewater application to soils [59-65].

\subsection{Effects of Soil Organic Matter (OM) and Soil Texture on Soil Pollution}

Although the use of raw urban wastewater in irrigation can lead to soil polluted with heavy metals, other physiochemical properties such as soil organic matter and soil texture are often even more important [66]. The content of OM in the soil had a positive effect on soil heavy metal content [16]. The impact of soil organic matter on available heavy metal concentration in the different studied soils is elucidated through a number of relationships (Figure 2). These relationships showed that the soil $\mathrm{OM}$ has a positive strong correlation with $\mathrm{Pb}, \mathrm{Cd}, \mathrm{Cu}, \mathrm{Ni}$, and $\mathrm{Fe}(\mathrm{r}=0.92,0.88,0.77,0.83$, and 0.85 , respectively) and is highly correlated with $\mathrm{Mn}(\mathrm{r}=0.63)$. On the other hand, there is a weak positive relationship with $\mathrm{Zn}(\mathrm{r}=0.46)$.

The different soil textures in the study area can be classified as clay, sandy clay loam, clay loam, and silt clay loam, with a dominance of clayey grade. Figure 3 shows the vertical distribution of clay, silt, and sand, by percentage, through the three studied horizons of the different profiles $(0-30,30-60$, and $60-90 \mathrm{~cm}$ ). Clayey soils irrigated by wastewater (for instance, profile No. 11 has a clay texture, with $62.09 \%$ clay content) have a higher total content of heavy metals than sandy soils (for instance, profile No. 6 has a sandy clay loam texture, with $51 \%$ total sand content) when irrigated by the same water source (Figure 3 and Table 2). 


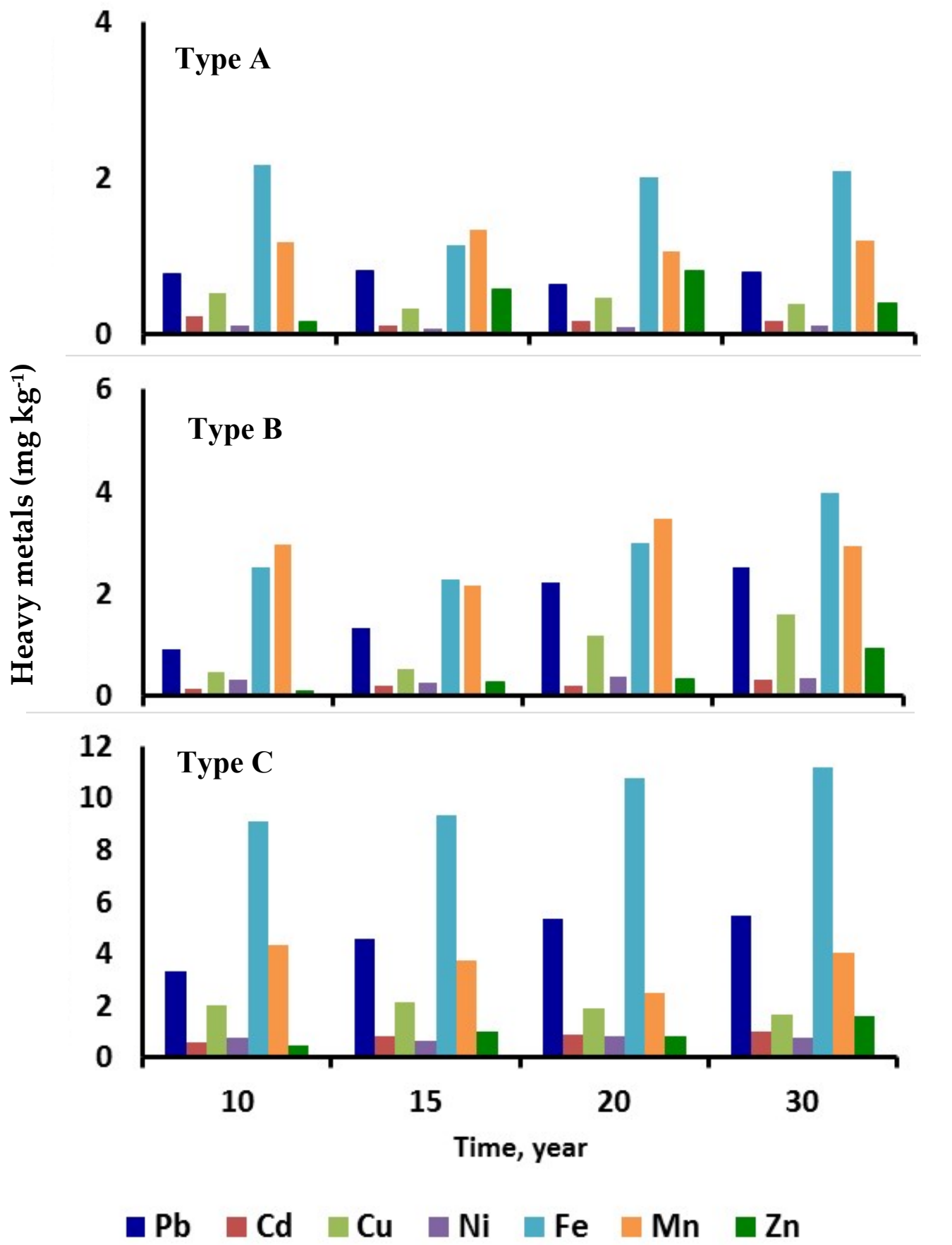

Figure 1. Temporal changes in soil heavy metal content due to wastewater addition in different studied soils. Type A: soils irrigated with Nile water; type B: soils irrigated with agricultural wastewater; type C: soils irrigated with raw urban wastewater.

In comparison with the permissible limits for heavy metals as specified by [53], the studied soils displayed levels of heavy metals within the maximum permissible limits, except for the Cd concentration in soil profile Nos. 11 and 12, which was above the permissible limits. Anthropogenic activities such as those associated with mining, smelting, the steel and iron industry, the chemical industry, traffic, agriculture, and domestic activities are the most significant producers of heavy metals in the environment. These heavy metals have an effect on soil ecology, agricultural production or product quality, and groundwater quality, as well as the health of living organisms through the food chain [67]. Soil texture has a direct impact on OM and CEC and consequently can be considered as a good indicator for the adsorption of heavy metals along soil profile [68]. Abd El-Aziz [69] reported that 
soils that have a coarse texture and low content of OM show the lowest levels of heavy metals, whereas soils having a clay texture contain the highest levels. Previous studies have reported that fine particles have a high ability to adsorb heavy metals due to their highly specific surface area as well as the presence of clay and organic matter content [70-75].
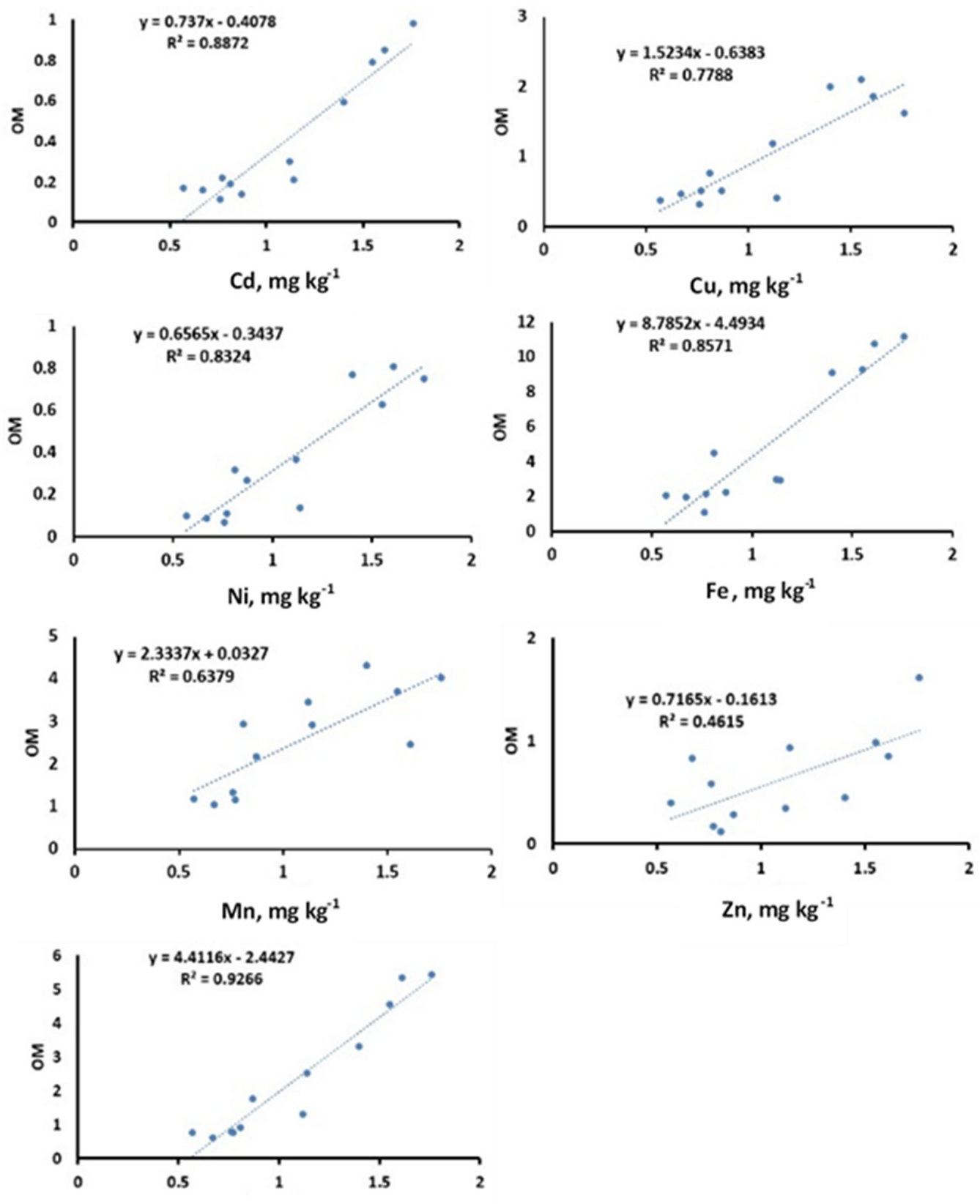

$\mathrm{Pb}, \mathrm{mg} \mathrm{kg}^{-1}$

Figure 2. Relationships between soil organic matter content and soil pollution in the studied soil profiles. 

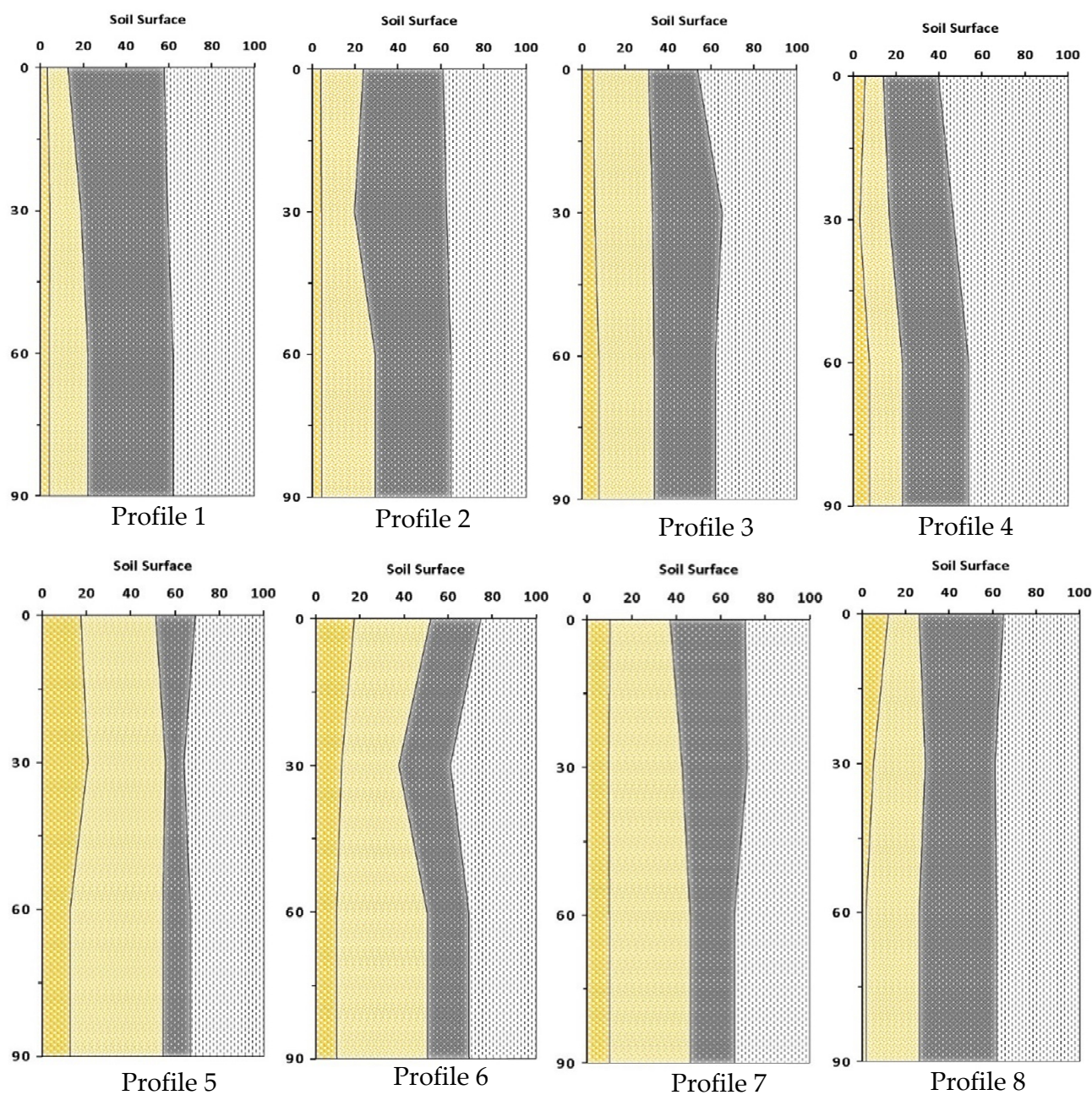

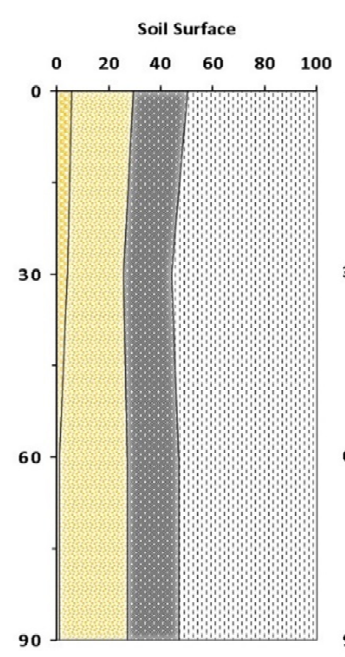

Profile 9

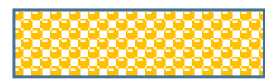

Coarse Sand
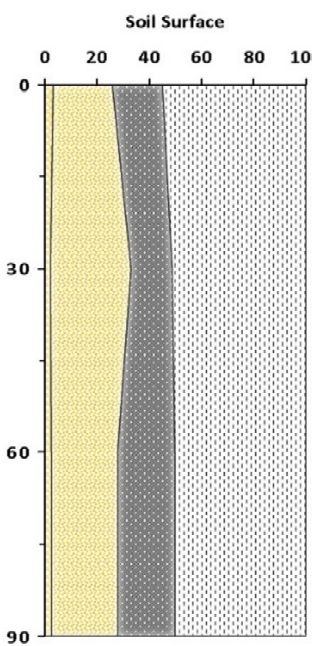

Profile 10

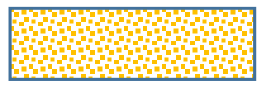

Fine Sand
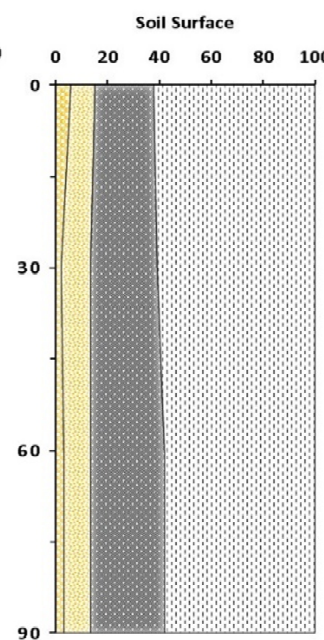

Profile 11
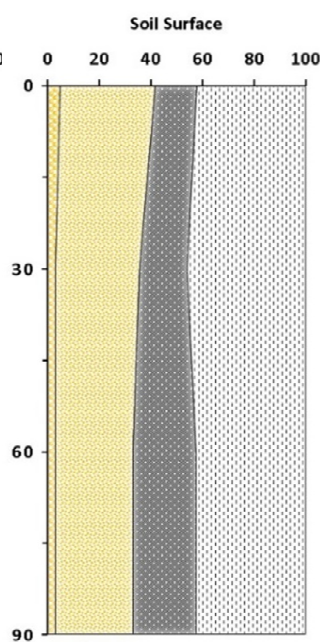

Profile 12

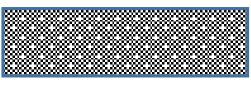

Silt

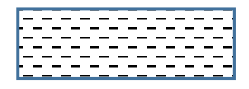

Clay

Figure 3. Vertical distribution of clay, silt and sand of different studied soil profiles; Profiles Nos. 1, 2, 3 and 4 represented the soils irrigated with Nile Water (control), profiles Nos. 5, 6, 7 and 8 represented the soils irrigated with agricultural wastewater, profiles Nos. 9, 10, 11 and 12 represented the soils irrigated with raw urban wastewater. 
Table 2. Average soil heavy metals content $\left(\mathrm{mg} \mathrm{kg}^{-1}\right)$ for the studied soil profiles.

\begin{tabular}{ccccccccc}
\hline Soil Types & Profile No. & ${ }^{*} \mathbf{P b}$ & ${ }^{*} \mathbf{C d}$ & ${ }^{*} \mathbf{C u}$ & ${ }^{*} \mathbf{N i}$ & ${ }^{*} \mathbf{F e}$ & ${ }^{*} \mathbf{M n}$ & ${ }^{*} \mathbf{Z n}$ \\
\hline & 1 & 0.77 & 0.22 & 0.52 & 0.11 & 2.17 & 1.17 & 0.16 \\
Soils irrigated with Nile water & 2 & 0.81 & 0.11 & 0.32 & 0.07 & 1.13 & 1.33 & 0.57 \\
& 3 & 0.62 & 0.16 & 0.47 & 0.09 & 2.00 & 1.05 & 0.81 \\
Soils irrigated with & 4 & 0.78 & 0.17 & 0.38 & 0.1 & 2.09 & 1.19 & 0.39 \\
agricultural wastewater & 5 & 0.92 & 0.19 & 0.77 & 0.32 & 4.51 & 2.95 & 0.11 \\
& 6 & 1.76 & 0.14 & 0.52 & 0.27 & 2.28 & 2.17 & 0.27 \\
Soils irrigated with raw urban & 7 & 1.32 & 0.3 & 1.19 & 0.37 & 3.00 & 3.47 & 0.33 \\
wastewater & 1 & 2.53 & 0.21 & 0.41 & 0.14 & 2.97 & 2.93 & 0.92 \\
& 11 & 3.32 & 0.59 & 2.00 & 0.77 & 9.11 & 4.33 & 0.44 \\
& 12 & 4.56 & 0.79 & 2.11 & 0.63 & 9.33 & 3.71 & 0.97 \\
& 5.34 & 0.85 & 1.87 & 0.81 & 10.77 & 2.47 & 0.83 \\
& 12 & 5.44 & 0.98 & 1.63 & 0.75 & 11.19 & 4.03 & 1.60 \\
\hline
\end{tabular}

* The permissible limit of heavy metals in unpolluted soils by Dutch ecologists; Lead $(\mathrm{Pb})=55$, Cadmium $(\mathrm{Cd})=0.76$, Coper $(\mathrm{Cu})=3.5$, Nickel $(\mathrm{Ni})=2.6$, Zinc $(\mathrm{Zn})=16 \mathrm{mg} \mathrm{kg}^{-1}$.

\subsection{Impact of Temporal Changes of Wastewater Addition on Soil Chemical Characteristics}

The mean values of $\mathrm{pH}$ in the studied soil profiles $\pm \mathrm{SD}$; either that soils irrigated with wasterwater or fresh water of Nile water (control), are shown in Figure 4A. Irrigation with raw urban wastewater declined soil $\mathrm{pH}$ values from $7.66 \pm 0.22$ to $7.32 \pm 0.25$ to $7.11 \pm 0.11$ for those soils which irrigated by S1, S2 and S3, respectively with a statistically significant difference between the different sources. This decrease in soil $\mathrm{pH}$ may be owing to the decomposition of OM into organic acid in soils irrigated with wastewater [68]. These results in agreement with the results reported by [76,77], and [78]. The soil $\mathrm{pH}$ has a major influence on the mobility, bioavailability, and transport of heavy metals in the soil. These changes depend on $\mathrm{pH}$ of the wastewater used for irrigation [79].

The maen soil EC values in the studied soil profiles \pm SD were $1.46 \pm 0.42,3.41 \pm 0.64$ and $11.04 \pm 4.97 \mathrm{dS} \mathrm{m}^{-1}$ for those soils which irrigated by S1, S2, and S3, respectively (Figure 4B). The statistical analysis observed that there is a significant difference between soils irrigated by raw urban wastewater (letter a) and both of soils irrigated by agriculture wastewaterand soils irrigated by Nile water (the same letter of $b$ ). The increase of soil EC can be due to the high salt quantities dissolved in wastewater. Increasing in soil EC may lead to an increase in soil salinity, and consequently, occurring soil quality and productivity problems. Limited availability of Nile water and using the mixed water to irrigate wide areas is the effective cause in soil salinization [80]. The soils of these districts, close to Qaroun Lake, suffering from water logging (water table $<60 \mathrm{~cm}$ ), seepage from the lake saline water $\left(43,000 \mathrm{mg} \mathrm{L}^{-1}\right)$ to the surrounding low relief lands causing salinity soil $\left(E C>4 \mathrm{dS} \mathrm{m}^{-1}\right)$ [24]. In winter, the farmers don't irrigate their soils for more than two months, but the soils does not dry out, and thus spotting germination occurred [24]. From the agronomic point of view, the challenge raised by irrigation with saline water is how to cope with these negative effects while maintaining acceptable crop yields [24]. Effective control of soil salinization in these districts is impractical due to limited availability of Nile water and the limited extension of using mixed water to irrigate wide areas. However, salt-affected areas could be managed through improvement process such as appropriate land uses, suitable agricultural practices and management, efficient drainage and irrigation systems, selection of salt-tolerant plant species based on salinity problem, and fertility management. These results are in qualitative agreement with the results of [81-83]. Increasing the salinity enhances the heavy metals solubility, thus causing greater availability of metals in the soil $[84,85]$. 

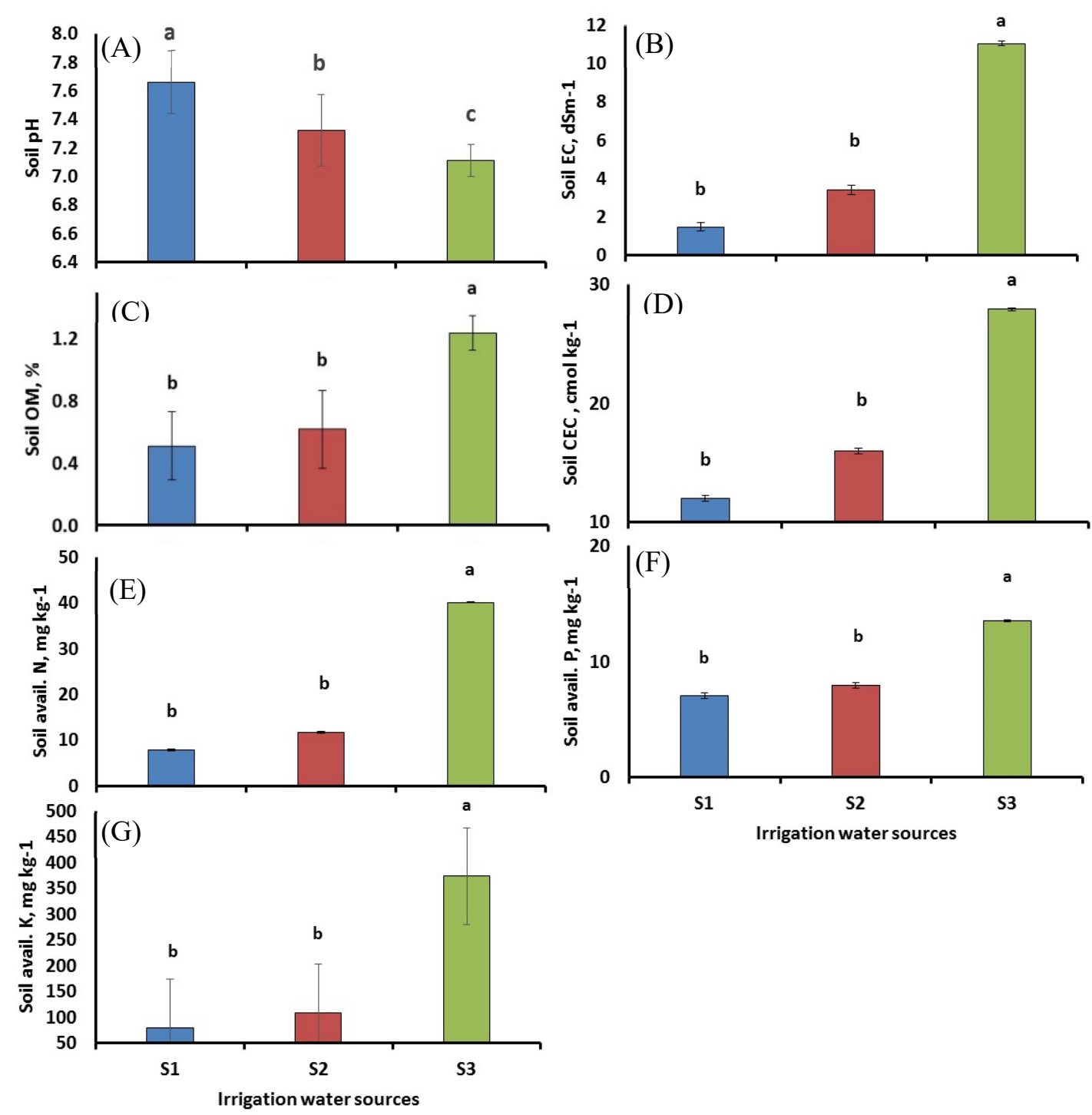

Figure 4. Effect of different water sources (S1, S2, and S3) on chemical properties of the studied soil profiles using variance analysis: (A) soil pH, (B) soil EC, (C) soil OM, (D) soil CEC, (E) soil available N, (F) soil available P, and (G) soil available K. Values are presented as means \pm standard deviation (SD) using number of the studied soil profiles $(n=12)$. For each attribute, bars with different superscript letters $(a, b$, and $c)$ denote significant difference between the effects of types of irrigation water at $p<0.05$. Appearance of the same letter means that the difference was not significant.

The mean soil OM values in the studied soil profiles \pm SD varied between $1.24 \pm 0.53 \%$ for soils irrigated by raw urban wastewater, $0.62 \pm 0.42 \%$ for soil irrigated with agricultural wastewater, and $0.51 \pm 0.33 \%$ for soils irrigated by Nile water (Figure $4 \mathrm{C}$ ). Moreover, the soil OM content was significantly boosted by irrigation with raw urban wastewater. The richness of soil OM enhanced the abundance of earthworms, which in turn has positively influenced the total porosity of the soil, thus a positive effect on soil productivity. The results are in agreement with the findings of $[16,54,58,68,77]$, which clarified the role of wastewater long use on soil organic matter, consequently, increasing microbial activity.

The raw urban wastewater exposed a high value of soil CEC indicating a positive effect on nutritional capacity of the soil, accordingly, high soil productivity. The mean value $\pm \mathrm{SD}$ of soil CEC was $27.88 \pm 8.05 \mathrm{cmol} \mathrm{kg}^{-1}$ in soil irrigated by raw urban wastewater (Figure 4D). While, there were no significant differences between soils irrigated by S1 and S2, which were $12 \pm 4.79$ and $16 \pm 6.85$. Numerous studies were stated on the impact of the long-term use of wastewater on soil CEC, eventually, on soil productivity by $[16,68,78,86-89]$. 
Regarding the available macro nutrients content in soils irrigated with different sources. The results presented in Figure 4E-G for available nitrogen, available phosphorous, and available potassium, respectively. The soils irrigated with raw urban wastewater showed a significant differences compared with the other sources, where, these soils have mean values $\pm \mathrm{SD}$ of $40.08 \pm 14.29,13.53 \pm 4.15$, and $373.96 \pm 266.5 \mathrm{mg} \mathrm{kg}^{-1}$ for NPK, respectively. The value of available phosphorous in these soils irrigated by raw urban wastewater tended to be high indicating excessive application of nutrients through chemical or organic fertilizers and using untreated raw urban wastewater compounds with the intensification of agriculture [90]. Li et al. [91] indicated that wastewater irrigation can effectively elevate soil nutrient contents, improving soil fertility. Conversely, Excess nitrogen and phosphorous in irrigation water can cause algal blooms and eutrophication [92]. Goher et al. [93] reported similar observations that El-wadi and El-Bats (the main irrigation source in the study area) having a mean $\mathrm{PO}_{4}-\mathrm{P}$ of $172.7,162.5 \mu \mathrm{gL}^{-1}$, respectively, and the total phosphorous reached about $339.9,331.7 \mu \mathrm{gL}^{-1}$, respectively. Using wastewater application was remunerative for soil fertility, but the associated decline in $\mathrm{pH}$ might result in an important loose of nutrients [63,94]. These results are in agreement with those of $[33,86,95-100]$.

\section{Conclusions}

The present study investigated the salinity and heavy metal concentrations in soil irrigated with wastewater and found levels much higher than in soil irrigated with Nile water but still under the admissible limits recommended by the FAO [48].

In contrast, wastewater usage in irrigation for longer periods $(10,15,20$, and 30 years) enhanced most of the studied soil properties, including OM, CEC, available $\mathrm{N}$, available $\mathrm{P}$, and available $\mathrm{K}$. The factor that had the largest influence on soil heavy metal pollution after long periods of wastewater addition was soil texture.

It can be concluded that, while wastewater from the El-Fayoum Governorate offers a supplementary irrigation water source, its long-term application may cause an accumulation of toxic elements such as $\mathrm{Pb}, \mathrm{Ni}, \mathrm{Cd}$, and $\mathrm{Fe}$; thus, there is a concern related to potentially toxic elements. To avoid the harmful effects of applied wastewater, there is a need for consistent assessment of both irrigation water and irrigated soils in order to ensure sustainable agriculture. Furthermore, remediation techniques along with management plans are needed in the study area to achieve improved soil properties. To increase soil productivity, the following steps are recommended: construction of two integrated wastewater treatment plants for El-Bats and El-Wadi drains; control of industrial activities (pretreatment); periodic maintenance of the existent wastewater treatment plants to maintain efficiency; control of unplanned urban sprawl to avoid increasing demand for available water resources.

Author Contributions: Conceptualization, M.A.A., S.A.S. and E.M.W.A.-H.; methodology, M.A.A.; validation, M.A.A., S.A.S. and E.M.W.A.-H.; formal analysis, M.A.A., S.A.S., E.M.W.A.-H. and M.Z.; investigation, M.A.A. and S.A.S.; resources, Z.V.; data curation, M.A.A.; writing-original draft preparation, M.A.A. and Z.V.; writing—review and editing, M.A.A. and M.Z.; visualization, M.A.A.; supervision, M.Z.; project administration, Z.V.; funding acquisition, Z.V. All authors have read and agreed to the published version of the manuscript.

Funding: This research received no external funding.

Institutional Review Board Statement: Not applicable.

Informed Consent Statement: Not applicable.

Data Availability Statement: Data is contained only within the article.

Acknowledgments: The authors are grateful for the support from Faculty of Agriculture, Zagazig University, Egypt. The authors are grateful for the support from the Ministry of Education of the Slovak Republic, VEGA 1/0217/19, Research of Hybrid Blue and Green Infrastructure as Active Elements of a Sponge City, and the Slovak Research and Development Agency, APVV-18-0360, Active Hybrid Infrastructure Towards the Sponge City. 
Conflicts of Interest: The authors declare no conflict of interest.

\begin{abstract}
Abbreviations
S1: Nile water; S2: Agricultural wastewater; S3: Raw urban wastewater; Type A: Soils irrigated by Nile water; Type B: Soils irrigated by agriculture wastewater; Type C: Soils irrigated by raw urban wastewater; $\mathrm{EC}_{\mathrm{W}}$ : Electrical conductivity; $\mathrm{SAR}$ : sodium adsorption ratio; OM: Soil organic matter; CEC: Cation exchange capacity.
\end{abstract}

\title{
References
}

1. Zarei, Z.; Karami, E.; Keshavarz, M. Co-production of knowledge and adaptation to water scarcity in developing countries. J. Environ. Manag. 2020, 262, 110283. [CrossRef] [PubMed]

2. Boazar, M.; Yazdanpanah, M.; Abdeshahi, A. Response to water crisis: How do Iranian farmers think about and intent in relation to switching from rice to less water-dependent crops? J. Hydrol. 2019, 570, 523-530. [CrossRef]

3. Talat, N. Recent trends and research strategies for treatment of water and wastewater in India. In Water Conservation and Wastewater Treatment in BRICS Nations, Technologies, Challenges, Strategies and Policies, 1st ed.; Singh, P., Milshina, Y., Tian, K., Gusain, D., Bassin, J., Eds.; Elsevier: Amsterdam, The Netherlands, 2020; p. 390.

4. Galavi, M.; Jalali, A.; Ramroodi, M.; Mousavi, S.R.; Galavi, H. Effects of treated municipal wastewater on soil chemical properties and heavy metal uptake by sorghum (Sorghum bicolor L.). J. Agric. Sci. 2010, 2, 235-241. [CrossRef]

5. Walker, C.; Lin, H.S. Soil property changes after four decades of wastewater irrigation: A landscape perspective. Catena 2008, 73, 63-74. [CrossRef]

6. Chang, W.; Tran, H.; Park, D.; Zhang, R.; Ahn, D. Ammonium nitrogen removal characteristics of zeolite media in a Biological Aerated Filter (BAF) for the treatment of textile wastewater. J. Ind. Eng. Chem. 2009, 15, 524-528. [CrossRef]

7. El-Hassanin, A.S.; Samak, M.R.; Abdel-Rahman, G.N.; Abu-Sree, Y.H.; Saleh, E.M. Risk assessment of human exposure to lead and cadmium in maize grains cultivated in soils irrigated either with low-quality water or freshwater. Toxicol. Rep. 2020, 7, 10-15. [CrossRef]

8. Abdel-Rahman, G.N.; Ahmed, M.B.M.; Saleh, E.M.; Fouzy, A.S.M. Estimated heavy metal residues in Egyptian vegetables in comparison with previous studies and recommended tolerable limits. J. Biol. Sci. 2018, 18, 135-143. [CrossRef]

9. Mahmoud, E.K.; Ghoneim, A.M. Effect of polluted water on soil and plant contamination by heavy metals in El-Mahla El-Kobra, Egypt. Solid Earth 2016, 7, 703-711. [CrossRef]

10. Murtaza, G.; Ghafoor, A.; Qadir, M. Accumulation and implications of cadmium, cobalt and manganese in soils and vegetables irrigated with city effluent. J. Sci. Food Agric. 2008, 88, 100-107. [CrossRef]

11. Hamilton, A.J.; Stagnitti, F.; Xiong, X.; Kreidl, S.L.; Benke, K.K.; Maher, P. Wastewater irrigation: The state of play. Vadose Zone 2007, 6, 823-840. [CrossRef]

12. Rajkumar, R.H.; Nemichandrappa, M.; Anilkumar, T.D.; Ayyanagowdar, M.S.; Polisgowdar, B.S.; Satyanarayana, R.; Vishwanatha, J. Effect of different irrigation methods and saline water on soil properties in tomato (Solanum lycopersicum) crop under vertisols of Tungabhadra project command. Int. J. Chem. Stud. 2019, 7, 2952-2957.

13. Leng, G.; Leung, L.R.; Huang, M. Significant impacts of irrigation water sources and methods on modeling irrigation effects in the ACME Land Model. J. Adv. Modeling Earth Sys. 2017, 9, 1665-1683. [CrossRef]

14. Ibekwe, A.M.; Gonzalez-Rubio, A.; Suarez, D.L. Impact of treated wastewater for irrigation on soil microbial communities. Sci. Total Environ. 2018, 622-623, 1603-1610. [CrossRef] [PubMed]

15. Bedbabis, S.; Ben Rouina, B.; Boukhris, M.; Ferrara, G. Effect of irrigation with treated wastewater on soil chemical roperties and infiltration rate. J. Environ. Manag. 2014, 133, 45-50. [CrossRef] [PubMed]

16. Ganjegunte, G.; Ulery, A.; Niu, G.; Wu, Y. Organic carbon, nutrient, and salt dynamics in saline soil and switchgrass (Panicum virgatum L. irrigated with treated municipal wastewater. Land Degrad. Dev. 2018, 29, 80-90. [CrossRef]

17. Ofori, S.; Puškáčová, A.; Růžičková, I.; Wanner, J. Treated wastewater reuse for irrigation: Pros and cons. Sci. Total Environ. 2021, 760, 144026. [CrossRef] [PubMed]

18. Abd Ellah, R.G. Water resources in Egypt and their challenges, Lake Nasser case study. Egypt. J. Aquat. Res. 2020, 46, 1-12. [CrossRef]

19. Luo, P.; Sun, Y.; Wang, S.; Wang, S.; Lyu, J.; Zhou, M.; Nakagami, K.; Takara, K.; Nover, D. Historical assessment and future sustainability challenges of Egyptian water resources management. J. Clean. Prod. 2020, 263, 121154. [CrossRef]

20. Omar, M.E.O.; Moussa, A.M.A. Water management in Egypt for facing the future challenges. J. Adv. Res. 2016, 7, 403-412. [CrossRef]

21. Attia, A.H.; El-Sayed, S.A.; El-Sabagha, M.E. Utilization of GIS modeling in geoenvironmental studies of Qaroun Lake, El Fayoum Depression. Egypt. J. Afr. Earth Sci. 2018, 138, 58-74. [CrossRef]

22. Kotb, M.M.; Ali, R.R.; El Semary, M.A. Use of remote sensing and GIS for land degradation assessment of Qarun Lake Coastal Area, El-Fayoum, Egypt. In Water and Land Security in Drylands, 1st ed.; Ouessar, M., Gabriels, D., Tsunekawa, A., Evett, S., Eds.; Springer: Cham, Switzerland, 2017. 
23. Abd-Elgawad, M.; Shendi, M.M.; Sofi, D.M.; Abdurrahman, H.A.; Ahmed, A.M. Innovative Thinking and Use of Marginal Soil and Water Resources in Irrigated Agriculture. In Developments in Soil Salinity Assessment and Reclamation, 1st ed.; Shahid, S.A., Abdelfattah, M.A., Taha, F.K., Eds.; Springer Nature: Dordrecht, Switzerland, 2013; p. 808. [CrossRef]

24. El-Zeiny, A.M.; El Kafrawy, S.B.; Ahmed, M.H. Geomatics based approach for assessing Qaroun Lake pollution. Egypt. J. Remote Sens. Space Sci. 2019, 22, 279-296. [CrossRef]

25. Al-Afify, A.D.G.; Tahoun, U.M.; Abdo, M.H. Water Quality Index and Microbial Assessment of Lake Qarun, El-Batts and El-Wadi Drains, Fayoum Province, Egypt. Egypt. J. Aquat. Biol. Fish. 2019, 23, 341-357. [CrossRef]

26. Abdel Wahed, M.S.M.; Mohamed, E.A. Assessment of water quality in surface waters of the Fayoum watershed, Egypt. Environ. Earth Sci. 2015, 74, 1765-1783. [CrossRef]

27. Mukherjee, S.; Nelliyat, P. Ground Water Pollution and Emerging Environmental Challenges of Industrial Effluent Irrigation: A Case Study of Mettupalayam Taluk, Tamilnadu; Madras School of Economics Working Paper; 2007; 52p, Available online: https: / / ssrn.com/abstract=1021153 (accessed on 9 August 2021).

28. Hajjami, K.; Ennaji, M.M.; Fouad, S.; Oubrim, N.; Khallayoune, K.; Cohen, N. Assessment of helminths health risk associated with reuse of raw and treated wastewater of the settat city (Morocco). Resour. Environ. 2012, 2, 193-201. [CrossRef]

29. Saliba, R.; Callieris, R.; D'Agostino, D.; Roma, R.; Scardigno, A. Stakeholders' attitude towards the reuse of treated wastewater for irrigation in Mediterranean agriculture. Agric. Water Manag. 2018, 204, 60-68. [CrossRef]

30. Barber, L.B.; Rapp, J.L.; Kandel, C.; Keefe, S.H.; Rice, J.; Westerhoff, P.; Bertolatus, D.W.; Vajda, A.M. Integrated assessment of wastewater reuse, exposure risk, and fish endocrine disruption in the Shenandoah River watershed. Environ. Sci. Tech. 2019, 53, 3429-3440. [CrossRef] [PubMed]

31. Yadav, R.K.; Goyal, B.; Sharma, R.K.; Dubey, S.K.; Minhas, P.S. Post irrigation impact of domestic sewage effluent on composition of soils, crops and groundwater e a case study. Environ. Int. 2002, 28, 481-486. [CrossRef]

32. Tarchouna, L.G.; Merdy, P.; Raynaud, M.; Pfeifer, H.R.; Lucas, Y. Effects of long term irrigation with treated wastewater. Part I: Evolution of soilchemicalproperties. Appl. Geochem. 2010, 25, 1703-1710. [CrossRef]

33. Abd-Elwahed, M.S. Influence of long-term wastewater irrigation on soil quality and its spatial distribution. Ann. Agric. Sci. 2018, 63, 191-199. [CrossRef]

34. Malhat, F.M.; Nasr, I. Metals in water from the River Nile tributaries in Egypt. Bull. Environ. Contam. Toxicol. 2012, 88, 594-596. [CrossRef] [PubMed]

35. Bardhan, G.; Russo, D.; Goldstein, D.; Levy, G.J. Changes in the hydraulic properties of a clay soil under long-term irrigation with treated wastewater. Geoderma 2016, 264, 1-9. [CrossRef]

36. Erel, R.; Eppel, A.; Yermiyahu, U.; Ben-Gal, A.; Levy, G.; Zipori, I.; Schaumann, G.E.; Mayer, O.; Dag, A. Long-term irrigation with reclaimed wastewater: Implications on nutrient management, soil chemistry and olive (Olea europaea L.) performance. Agric. Water Manag. 2019, 213, 324-335. [CrossRef]

37. Schacht, K.; Marschner, B. Treated wastewater irrigation effects on soil hydraulic conductivity and aggregate stability of loamy soils in Israel. J. Hydrol. Hydro. 2015, 63, 47-54. [CrossRef]

38. Ali, R.R.; Abdel Kawy, W.A.M. Land degradation risk assessment of El Fayoum depression, Egypt. Arab. J. Geosci. 2012, 6, 2767-2776. [CrossRef]

39. Soil Survey Staff. Keys to Soil Taxonomy, 12th ed.; U.S. Department of Agriculture; Natural Resources Conservation Service (NRCS); Lulu.com: Washington, DC, USA, 2014; p. 353.

40. El-Sayed, S.A.; Moussa, E.M.M.; El-Sabagh, M.E.I. Evaluation of heavy metal content in Qaroun Lake, El-Fayoum, Egypt. Part I: Bottom sediments. J. Radiat. Res. Appl. Sci. 2015, 8, 276-285. [CrossRef]

41. Omar, M.M. Evaluation of actions for better water supply and demand management in Fayoum, Egypt using RIBASIM. Water Sci. 2013, 27, 78-90. [CrossRef]

42. Rice, E.W.; Rodger, B.B.; Andrew, D.E.; Leonore, S.C. Standard Methods for the Examination of Water and Wastewater, 20th ed.; American Public Health Association (APHA): Washington, DC, USA, 2012; p. 2671.

43. Rodier, J.; Bernard, L.; Nicole, M. L'analyse de L'eau, 9th ed.; DUNOD: Paris, French, 2009; p. 1384.

44. Soltanpour, P.; Workman, S. Modification of the $\mathrm{NH}_{4} \mathrm{HCO}_{3}$-DTPA soil test to omit carbon black. Commun. Soil Sci. Plant Anal. 1979, 10, 1411-1420. [CrossRef]

45. Walkley, A.; Black, I.A. An examination of the Degtjareff method for determining soil organic matter, and a proposed modification of the chromic acid titration method. Soil Sci. 1934, 37, 29-38. [CrossRef]

46. Jackson, M.L. Soil Chemical Analysis, 2nd ed.; Parallel Press, UW-Madison Libraries: Madison, WI, USA, $2005 ;$ p. 895.

47. Black, C.A.; Evans, D.D.; Dinauer, R. Methods of Soil Analysis; American Society of Agronomy: Madison, WI, USA, 1965; Volume 9, pp. 653-708.

48. Watanabe, F.S.; Olsen, S.R. Test of an ascorbic acid method for determining phosphorus in water and $\mathrm{NaHCO}_{3}$ extracts from soil. Soil Sci. Soc. 1965, 29, 677-678. [CrossRef]

49. Bünemann, E.K.; Bongiorno, G.; Bai, Z.; Creamer, R.E.; De Deyn, G.; de Goede, R.; Mäder, P. Soil quality-A critical review. Soil Biol. Biochem. 2018, 120, 105-125. [CrossRef]

50. Gee, G.W.; Bauder, J.W. Particle-size analysis. In Methods of Soil Analysis, Part 1, 2nd ed.; Klute, A., Ed.; American Society of Agronomy: Madison, WI, USA, 1986; Volume 9, pp. 383-409. 
51. WHO/FAO. Joint FAO/WHO Food Standard Programme Codex Alimentarius Commission 13th Session. In Proceedings of the Thirty-Eight Session of the Codex Committee on Food Hygiene, Houston, United States of America, Alinorm, Washington, DC, USA, 29 March-03 April 2004.

52. Belghyti, D.; El Guamri, Y.; Ztit, G.; Ouahidi, M.L.; Joti, M.B.; Harchrass, A.; Amghar, H.; Bouchouata, O.; El Kharrim, K.; Bounouira, H. Caracterisation physicochimique des eaux usées d'abattoir en vue de la mise en oeuvre d'un traitement adéquat: Cas de kénitra au maroc. Afr. Sci. 2009, 5, 199-216.

53. Ministry of Housing. Physical planning and Environmental Conservation; Report HSE 94.021; European Environment Agency: Copenhagen, Denmark, 1994; p. 100.

54. Ababsa, N.; Kribaa, M.; Tamrabet, L.; Addad, D.; Hallaire, V.; Ouldjaoui, A. Long-term effects of wastewater reuse on hydro physicals characteristics of grassland grown soil in semi-arid Algeria. J. King Saud Univ. Sci. 2020, 32, 1004-1013. [CrossRef]

55. Kwiatkowska-Malina, J. Functions of organic matter in polluted soils: The effect of organic amendments on phytoavailability of heavy metals. Appl. Soil Ecol. 2018, 123, 542-545. [CrossRef]

56. Cao, S.P. Vertical distribution of heavy metal pollutant in soil profiles of Tianjin. Contrib. Geol. Miner. Resour. Res. 2004, 19, 270-274.

57. Dotaniya, M.L.; Rajendiran, S.; Meena, V.D.; Coumar, M.V.; Saha, J.K.; Kundu, S.; Patra, A.K. Impact of long-term application of sewage on soil and crop quality in vertisols of Central India. Bull. Environ. Contam. Toxicol. 2018, 101, 1-8. [CrossRef] [PubMed]

58. Ahmad, K.; Wajid, K.; Khan, Z.I.; Ugulu, I.; Memoona, H.; Sana, M.; Nawaz, K.; Malik, I.S.; Bashir, H.; Sher, M. Evaluation of potential toxic metals accumulation in wheat irrigated with wastewater. Bull. Environ. Contam. Toxicol. 2019, 102, 822-828. [CrossRef]

59. Papaioannou, D.; Kalavrouziotis, I.K.; Koukoulakis, P.H.; Papadopoulos, F.; Psoma, P. Interrelationships of metal transfer factor under wastewater reuse and soil pollution. J. Environ. Managem. 2018, 216, 328-336. [CrossRef]

60. Fang, W.; Delapp, R.C.; Kosson, D.S.; van der Sloot, H.A.; Liu, J. Release of heavy metals during long-term land application of sewage sludge compost: Percolation leaching tests with repeated additions of compost. Chemosphere 2017, 169, 271-280. [CrossRef]

61. Guo, H.; Nasir, M.; Lv, J.; Dai, Y.; Gao, J. Understanding the variation of microbial community in heavy metals contaminated soil using high throughput sequencing. Ecotoxicol. Environ. Saf. 2017, 144, 300-306. [CrossRef]

62. Khaskhoussy, K.; Kahlaoui, B.; Nefzi, B.M.; Jozdan, O.; Dakheel, A.; Hachicha, M. Effect of treated wastewater irrigation on heavy metals distribution in a tunisian soil. Eng. Technol. Appl. Sci. 2015, 5, 805-810. [CrossRef]

63. Singh, P.; Deshbhratar, P.; Ramteke, D. Effects of sewage wastewater irrigation on soil properties, crop yield and environment. Agric. Water Manag. 2012, 103, 100-104. [CrossRef]

64. Yaylali-Abanuz, G. Heavy metal contamination of surface soil around Gebze industrial area. Turk. Microchem. J. 2011, 99, 82-92. [CrossRef]

65. El-Nennah, M.; El-Kobbia, T.; Shehata, A.; El-Gamal, I. Effect of irrigation loamy sand soil by sewage effluents on its content of some nutrients and heavy metals. Plant Soil 1982, 65, 289-292. [CrossRef]

66. Hang, X.; Wang, H.; Zhou, J.; Ma, C.; DU, C.; Chen, X. Risk assessment potentially toxic element contamination in soil and rice (Oryza sativa) in a typical area of Yangtze River delta. Environ. Pollut. 2009, 157, 2542. [CrossRef]

67. Ene, A.; Popescu, I.V.; Stihi, C. Applications of proton-induced Xray emission technique inmaterials and environmental science. Ovidius Univ. Ann. Chem. 2009, 20, 35.

68. Abd-Elwahed, M.S. Effect of long-term wastewater irrigation on the quality of alluvial soil for agricultural sustainability. Ann. Agric. Sci. 2019, 64, 151-160. [CrossRef]

69. Abd El-Aziz, S.H. Guideline references to levels of heavy metals in arable soils in upper Egypt. J. Saudi Soc. Agric. Sci. 2021, article in press.

70. Ljung, K.; Selinus, O.; Otabbong, E.; Berglund, M. Metal and arsenic distribution in soil particle sizes relevant to soil ingestion by children. Appl. Geochem. 2006, 21, 1613-1624. [CrossRef]

71. Parizanganeh, A. Grain Size Effect on Trace Metals in Contaminated Sediments Along the Iranian Coast of the Caspian Sea. In Proceedings of the 12th World Lake Conference, Jaipur, India, 28 October-2 November 2007; Volume 329, p. 336.

72. Quenea, K.; Lamy, I.; Winterton, P.; Bermond, A.; Dumat, C. Interactions between metals and soil organic matter in various particle size fractions of soil contaminated with waste water. Geoderma 2009, 149, 217-223. [CrossRef]

73. Rafiei, B.; Bakhtiari, N.M.; Hashemi, M.; Khodaei, A.S. Distribution of Heavy Metals around the Dashkasan Au Mine. Int. J. Environ. Res. 2010, 4, 647-654.

74. Beamer, P.I.; Elish, C.A.; Roe, D.J.; Loh, M.M.; Layton, D.W. Differences in metal concentration by particle size in house dust and soil. J. Environ. Monitor. 2012, 14, 839-844. [CrossRef]

75. Zhang, H.; Luoa, Y.; Makino, T.; Wu, L.; Nanzyo, M. The heavy metal partition in size-fractions of the fine particles in agricultural soils contaminated by waste water and smelter dust. J. Hazard. Mater. 2013, 248-249, 303-312. [CrossRef]

76. Kavvadias, V.; Elaiopoulos, K.; Theocharopoulos, S.; Soupios, P. Fate of potential contaminants due to disposal of olive mill wastewaters in unprotected evaporation ponds. Bull. Environ. Contam. Toxicol. 2017, 98, 323-330. [CrossRef] [PubMed]

77. Khai, N.M.; Tuan, P.T.; Vinh, N.C.; Oborn, I. Effects of using wastewater as nutrient sources on soil chemical properties in peri-urban agricultural systems. VNU J. Sci. Earth Environ. Sci. 2016, 24, 87-95. 
78. Vaseghi, S.; Afyuni, M.; Shariatmadari, H.; Mobli, M. Effect of sewage sludge on some nutrients concentration and soil chemical properties. J. Isfahan Water Wastewater 2005, 53, 15-19.

79. Nigam, R.; Srivastava, S.; Prakash, S.; Srivastava, M.M. Cadmium mo-bilisation and plant availability-the impact of organic acids commonly ex- uded from roots. Plant Soil 2001, 230, 107-113. [CrossRef]

80. Boroojeni, A.K.; Noorbakhsh, F.; Afyuni, M.; Shariatmadari, H. Different forms of lead, nickel and cadmium in a calcareous soil treated with sewage sludge. J. Sci. Technol. Agric. Nat. Resour. 2007, 11, 41-53.

81. Russo, D.; Laufer, A.; Bar-Tal, A. Improving water uptake by trees planted on a clayey soil and irrigated with low-quality water by various management means: A numerical study. Agric. Water Managem. 2019, 229, 105891. [CrossRef]

82. Tarchitzki, J.; Bar-Tal, A.; Shenker, M.; Levy, G.; Eshel, A.; Cohen, S.; Russo, D.; Schwartz, A.; Ephrat, J.; Cohen, H.; et al. Examination of Treatments for the Prevention and Amendment of Damage Caused by TWW Irrigation in Orchards Planted on Clay Soils; Report 21-16-004 Submitted to the Chief Scientist of the Israeli Ministry of Agriculture and Rural Development (in Hebrew). 2019; Unpublished report.

83. Paudel, I.; Bar-Tal, A.; Levy, J.G.; Rotbart, N.; Ephrath, J.; Cohen, S. Treated wastewater (TWW) irrigation: Soil variables and Grapefruit tree performance. Agric. Water Manag. 2018, 204, 126-137. [CrossRef]

84. Ram, L.C.; Srivastava, N.K.; Tripathi, R.C.; Jha, S.K.; Sinha, A.K.; Singh, G.; Manoharans, V. Management of mine spoil for crop productivity with lignite fly ash and biological amendments. J. Environ. Manag. 2006, 79, 173-187. [CrossRef]

85. Singh, A.; Sharma, R.K.; Agrawal, M.; Marshall, F. Effects of wastewater irrigation on physicochemical properties of soil and availability of heavy metals in soil and vegetables. Commun. Soil Sci. Plant Anal. 2009, 40, 3469-3490. [CrossRef]

86. Bastida, F.; Jehmlich, N.; Martínez-Navarro, J.; Bayona, V.; García, C.; Moreno, J.L. The effects of struvite and sewage sludge on plant yield and the microbial community of a semiarid Mediterranean soil. Geoderma 2019, 337, 1051-1057. [CrossRef]

87. Sánchez-González, A.; Chapela-Lara, M.; Germán-Venegas, E.; Fuentes-García, R.; Del Río-Portilla, F.; Siebe, C. Changes in quality and quantity of soil organic matter stocks resulting from wastewater irrigation in formerly forested land. Geoderma 2017, 306, 99-107. [CrossRef]

88. Castro, E.; Manas, M.P.; Heras, J.L. Effects of wastewater irrigation on soil properties and turfgrass growth. Water Sci. Technol. 2011, 63, 1678. [CrossRef] [PubMed]

89. Karami, M.; Rezainezhad, Y.; Afyuni, M.; Shriatmadari, H. The cumulative and remains effects of municipal sewage sludge on the concentration of Lead $(\mathrm{Pb})$ and Cadmium $(\mathrm{Cd})$ in soil and yield of wheat. J. Sci. Technol. Agric. Nat. Resour. 2007, 11, 79-94.

90. Liu, C.; Dang, X.; Mayes, M.A.; Chen, L.; Zhang, Y. Effect of long-term irrigation patterns on phosphorus forms and distribution in the brown soil zone. PLOS ONE 2017, 12, 11. [CrossRef]

91. Li, P.; Wu, J.; Qian, H. Effects of Irrigation with Paper Wastewater on Soil Fertility. In Proceedings of the 2014 International Conference on Gis And Resource Management (ICGRM), Guangzhou, China, 3-5 January 2014; Available online: https: / /www. researchgate.net/publication/264235442_Effects_of_Irrigation_with_Paper_Wastewater_on_Soil_Fertility (accessed on 9 August 2021).

92. Kavita, U.; Piyush, M.; Gupta, A.K. Studies on the physico-chemical status of two ponds at Varanasi and Bhadohi under biotic stress. Plant Arch. 2010, 10, 691-693.

93. Goher, M.E.; El-Rouby, W.M.A.; El-Dek, S.I.; El-Sayed, S.M.; Noaemy, S.G. Water quality assessment of Qarun Lake and heavy metals decontamination from its drains using nanocomposites. The 4th International Conference on Advanced Applied Sciences. IOP Conf. Ser. Mater. Sci. Eng. 2018, 464, 012003. [CrossRef]

94. Kiziloglu, F.M.; Turan, M.; Sahin, U.; Kuslu, Y.; Dursun, A. Effects of untreated and treated wastewater irrigation on some chemical properties of cauliflower (Brassica olerecea L. var. botrytis) and red cabbage (Brassica olerecea L. var. rubra) grown on calcareous soil in Turkey. Agric. Water Manag. 2008, 95, 716-724. [CrossRef]

95. Cakmakci, T.; Sahin, U. Productivity and heavy metal pollution management in a silage maize field with reduced recycled wastewater applications with different irrigation methods. J. Environ. Managem. 2021, 291, 112602. [CrossRef]

96. Xu, J.; Wu, L.; Chang, A.C.; Zhang, Y. Impact of long-term reclaimed wastewater irrigation on agricultural soils: A preliminary assessment. J. Hazard. Mater. 2010, 183, 780-786. [CrossRef] [PubMed]

97. Farahat, E.; Linderholm, H.W. The effect of long-term wastewater irrigation on accumulation and transfer of heavy metals in Cupressus sempervirens leaves and adjacent soils. Sci. Total Environ. 2015, 512, 1-7. [CrossRef]

98. Abu-Hashim, M.; Sayed, A.; Zelenakova, M.; Vranayová, Z.; Khalil, M. Soil Water Erosion Vulnerability and Suitability under Different Irrigation Systems Using Parametric Approach and GIS, Ismailia, Egypt. Sustainability 2021, 13, 1057. [CrossRef]

99. Nasr, E.E.; Khater, Z.Z.; Zelenakova, M.; Vranayova, Z.; Abu-Hashim, M. Soil Physicochemical Properties, Metal Deposition, and Ultrastructural Midgut Changes in Ground Beetles, Calosoma chlorostictum, under Agricultural Pollution. Sustainability 2020, 12, 4805. [CrossRef]

100. Alnaimy, M.; Zelenakova, M.; Vranayova, Z.; Abu-Hashim, M. Effects of Temporal Variation in Long-Term Cultivation on Organic Carbon Sequestration in Calcareous Soils: Nile Delta, Egypt. Sustainability 2020, 12, 4514. [CrossRef] 